\title{
The Effect of Corporate Social Responsibility Practices on Brand Equity: An Examination of Malaysia's Top 100 Brands
}

\author{
Abdul Rahman ZAHARI ${ }^{*}$, Elinda ESA ${ }^{* *}$, Jegatheesan RAJADURAI ${ }^{* * *}$, Noor Azlinna AZIZAN $^{* * * *}$, \\ Puteri Fadzline MUHAMAD TAMYEZ ${ }^{* * * * *}$
}

Received: October 30, 2019 Revised: December 01, 2019 Accepted: December 18, 2019

\begin{abstract}
The study aims to provide some evidence of the effects of CSR practices on financial-based brand equity in Malaysia. Nowadays, many companies have embraced corporate social responsibility (CSR) practices because CSR is a vital component of the current competitive and complex business arena. It contributes greatly to social, environmental, and economic condition. With CSR practices, companies are able to achieve many benefits and there is evidence that CSR practices predict higher brand equity. However, little evidence has been produced concerning the effects of CSR practices on financial aspects of brand equity in developing countries such as Malaysia. Therefore, this paper aims to investigate the effects of CSR practices on financial based brand equity among Malaysia Top 100 brand. A CSR checklist instrument was used in the current study to examine the extent of CSR practiced. The results indicated that PLCs that were actively involved in CSR practices such as environmental, community, workplace and marketplace, found that this involvement enhanced their brand equity. The findings provide useful support and evidence for the management of PLCs in Malaysia, as well as companies in other developing countries, to engage more in CSR practices as a core element of their strategic and brand management.
\end{abstract}

Keywords : Corporate Social Responsibility, Brand Equity, Malaysia Public Listed Companies

JEL Classification Code : M3, M4, G3

\section{Introduction}

Globally, all types of firms, particularly large

${ }^{*}$ First Author and Corresponding Author. Senior Lecturer, College of Business Management \& Accounting, The Energy University (Universiti Tenaga Nasional), Malaysia [Postal

Address: Campus Sultan Haji Ahmad Shah, 26700 Muadzam Shah,Pahang, Malaysia] Tel. (+609) 4552061 Fax. (+609) 4552007, Email: rahman@uniten.edu.my

**Lecturer, College of Business Management \& Accounting, The Energy University, Malaysia. Email: elinda@uniten.edu.my

${ }^{* * *}$ Associate Professor, College of Business Management \& Accounting, The Energy University, Malaysia.

**** Professor, College of Business Administration, Prince Sultan University, Riyadh, Saudi Arabia [Postal Address: Prince Nasser Bin Farhan Street, Riyadh 12435, Saudi Arabia]

Email: nazizan@psu.edu.sa

***** Senior Lecturer, Faculty of Industrial Management, Universiti Malaysia Pahang, Malaysia. Email: fadzline@ump.edu.my

๑) Copyright: Korean Distribution Science Association (KODISA)

This is an Open Access article distributed under the terms of the Creative Commons Attribution NonCommercial License (https://creativecommons.org/licenses/by-nc/4.0/) which permits unrestricted noncommercial use, distribution, and reproduction in any medium, provided the original work is properly cited. organizations and conglomerates, are increasingly encouraged to implement corporate social responsibility (CSR) practices aimed at contributing to societal improvements due to the high expectations of their stakeholders (Mensah, Yensu, \& Atuilik, 2017; Golob \& Podnar, 2019).

These practices include positive actions towards the environment, social causes and communities. CSR practices can benefit organizations by promoting a positive public image creating a workplace with satisfied employees, happy customers and lower costs, and tackling environmental issues such as energy efficiency and waste management, and community engagement. These practices can be a win-win situation and inspire a relationship of trust between the firm and the community (Bhattacharya, 2017). Conversely, failure to meet the rising expectations of the global community may jeopardize a global brand's image and reputation (e.g. the Nike and The Gap sweatshop disputes) (Wang, 2010).

A study conducted by Palazo and Basu (2007) mentioned 
that a global shift in consumption patterns to more valuedriven consumption has led to changing dynamics in branding strategies of organizations. In response to this new consumption pattern, many organizations are now focusing more on building a socially responsible brand and communicating values rather than just concentrating on product features (Golob \& Podnar, 2019). Moreover, a longitudinal study demonstrated a consistent rise in the consumers' readiness to purchase products or use services that deliver higher social benefits. More importantly, consumers in advanced countries are using brand values as a filter for their support (or punishment) through their buying behavior (Cone Inc., 2017). With these concerns, many scholars have conducted research relating CSR practices to branding strategies, particularly brand equity (Fatma, Rahman, \& Khan, 2015; Feng, Yoon, \& He, 2016; Bhattacharya, 2017; Cowan \& Guzman, 2018; Golob \& Podnar, 2019). Aaker (1996) defined brand equity as assets associated with a brand name that increase the value of the product or service of an organization. Strong brand equity can help an organization distinguish itself from its competitors and provide financial benefits (Pakseresht, 2010; Ding, Ferreira, \& Wongchoti, 2016; Kang \& Namkung, 2017; Nair \& Bhattacharyya, 2019).

Brand equity can usually be conceptualized from the customer's perspective (customer-based brand equity) and the financial approach (financial-based brand equity). In measuring brand equity, most scholars use a technique based on consumer mindsets by testing dimensions of brand equity such as awareness, associations or attitudes. This approach was founded by Keller (1993) and Keller and Lehmann (2003). In particular, this paper adopts a financial-based brand equity where the brand value of the firm is calculated using a specific formula. Wang (2010) defined financial-based brand equity as the additional economic value a brand offers to a company in its relative potential to generate future earnings or cash flows. In this paper, the brand values of the public listed companies (PLCs) in Malaysia are taken from the Brand Finance Group. This paper is more focused on the financial perspective rather than customer mindsets because CSR practices tend to involve long-term efforts and a company often reaps the benefits of such investments over a longer period of time. Similarly, brand equity assessment should be forward looking because the outcomes of CSR practices are often long-term.

Many past studies have proved that overall CSR practices and specific CSR practices significantly influenced brand equity among organizations in both developed and developing countries (Bhattacharya \& Kaursar, 2016; Singh Dara Singh \& Islam, 2017; Lv, Wei, Li, \& Lin, 2019). Nevertheless, there still remains underexplored aspects of CSR practices and financial-based brand equity in developing countries such as Malaysia (Tilt, 2016; Choongo, 2017; Heinberg, Ozkaya, \& Taube, 2018; Yang \& Basile, 2019). Thus, the lack of evidence of the effects of CSR practices on financial-based brand equity in Malaysia has motivated the authors to conduct this study. The findings will extant work focuses on the effect of CSR practices on brand equity and offer a useful contribution to literature. Moreover, this paper augments existing theory (Shareholder Theory) by providing empirical evidence about the nature of the CSR practices-brand equity linkage. The findings will provide useful support and evidence for the management of the PLCs in Malaysia, as well as companies in other developing countries, to engage in more CSR practices as a core element of their strategic and brand management. Indirectly, the stakeholders will also gain more benefits from CSR practices undertaken by these companies.

\section{Literature Review}

\subsection{Theoretical Review}

In general, CSR is the way companies integrate social, environmental and economic concerns into their values, culture, decision making, strategies and operations in an accountable manner and thereby create better practices within the firm, create wealth and address their social responsibilities (Shahin \& Zairi, 2007). According to Carroll (1991), the first definition of CSR was formulated in 1953 and, in the years since, the concept has been continually challenged and developed further by academics and practitioners. For instance, some previous studies mentioned that CSR has been subdivided into numerous concepts or areas such as 'Corporate Social Responsiveness', 'Corporate Responsibility', 'Corporate Environmentalism' (Menon \& Menon, 1997), 'Corporate Social Performance' (Clarkson, 1995), and 'Corporate Citizenship' (Waddock, 2004). However, these concepts coexist side by side rather than developing from each other sequentially (Tiba, Rijnsoever, \& Hekkert, 2018).

Past literature has divided CSR into two general dimensions: external CSR practices and internal CSR practices. The most common operationalization of CSR has been rooted in the work of Carroll (1991) who provides the basic concepts of a firm's CSR that should encompass its economical, legal, ethical and voluntary activities in terms of social responsibility. Mensah et al. (2017) claim that the research into social responsibility has only concentrated on external CSR (community and environmental) and omitted the internal dimensions of CSR (workplace and marketplace). Because of this shortcoming, this study has incorporated the internal and external dimensions of CSR 
where the stakeholder's dimensions are used as dimensions of CSR (employees, shareholders, customers, suppliers and natural environments). Clarkson (1995) clearly stated that an organization's survival and success depends on the ability of its managers to create sufficient wealth and satisfaction within its primary stakeholders. This in turn will lead to the firm's competitive advantage (Barney \& Hansen, 1994). In view of this, the current research has adopted the Stakeholder Theory to study the effects of CSR practices on brand equity.

The Stakeholder Theory tells us that an organization is not only bound to serve the shareholders' needs but also the needs of different people or firms and is wholly responsible for creating good relationships with them (Jones, 2005). With regards to brand equity, the stakeholder concept gives a much clearer picture of sources of brand value and equity. This will eventually give an important tool for managing the stakeholder relationships (Jones, 2005). Clarke and Clegg (1998) have concluded that these responsibilities, practiced by many organizations, are strongly related to the concept of corporate citizenship which validates the Stakeholder Theory. Several past studies (Piercy \& Lane, 2009; Wang, 2010; Feng, Wang, \& Kreuze, 2017) have identified that stakeholders are vital and have a large impact in relation to CSR practices. They should be made operational, especially to examine the marketing benefits of CSR such as brand equity on stakeholder relations (Heinberg et al., 2018; Fornes, Lopez, de Haan, \& Blanch, 2019). As a result, people with authority in business are now recognizing CSR practices as important (Piercy \& Lane, 2009).

In Malaysia, CSR practices attracted considerable attention when Bursa Malaysia set out the framework for disclosure of CSR practices for PLCs on September 5, 2006. The purpose was to regulate companies when identifying CSR practices in the four dimensions of environment, community, workplace and marketplace. According to Evans and Kantrowitz (2002), environmental practices often refer to the overall situation on Earth or the healthy condition of people living in the environment. Based on this framework, organizations started implementing strategies for waste management, renewable energy, biodiversity and wildlife conservation, and focused more on green practices to reduce the pollution and waste which could destroy the environment. Meanwhile, the community is the place in which the business operation is performing. Therefore, the community-based CSR acknowledges employee volunteerism, school adoptions and internship programmes, contributions to underprivileged members of the community and scholarships. Community-based CSR is often very apparent to organizational stakeholders and is more likely to have a positive effect on brand equity (Feng, Wang, \& Kreuze, 2017).
On another note, workplace-oriented CSR refers to various issues such as labor relations, personal and professional conflict issues, health and safety, and discrimination and harassment that employees and employers might face while at work (Fox \& Stallworth, 2009). To reduce these concerns, many organizations have introduced common workplace practices for CSR such as promoting employees' safety and health, maternity and paternity leave and employee training (Torres, Bijmolt, Tribó, \& Verhoef, 2012). By doing this, the firms have the ability to create sustainable workplaces that ensure positive impacts on employees and their families. At the same time, it provides a working environment that motivates and enables employees to make their best contributions to business success and positively impacts on stakeholders.

Furthermore, marketplace activities should focus more on the customer service targets of the company and the ways to persuade suppliers and service providers to implement ethical procurement practices, using local suppliers when and where possible, and environmentally friendly materials. A voluntary supplier's score card has been implemented by some companies in order to encourage suppliers and service providers to disclose on how they measure their efforts to reduce greenhouse gasses, water and energy, especially in less developed countries (Kantabutra \& Avery, 2013). The demands by customers keep increasing since price and quality become more equal and they are looking for brand values that match their own environmental ideals (Faisal, 2010). Importantly, these actions also help to increase brand popularity and encourage brand loyalty among customers (Prakash, Choudharyb, Kumarc, Garza-Reyesd, Khane, \& Panda, 2019).

\subsection{Brand Equity}

Brand equity refers to the marketing effects or outcomes that accrue to a product with its brand name compared with those that would accrue if the same product did not have the brand name (Aaker, 1991; Keller, 2003). Tiwari (2010) added that brand equity is a set of customers' perceptions, behaviours and knowledge that creates the demand and/or price for a branded product. In brief, brand equity is what the brand is worth to the customer. According to Aaker (1996), brand equity can be measured in four dimensions: brand awareness, brand loyalty, perceived quality and brand associations. Meanwhile, from the shareholder's point of view, the value of a brand relies on the financial returns that the brand will generate over its useful life and can be potentially monetized as brand value (Willmott, 2010). Moreover, brand equity is better demonstrated as a single figure of brand value because it is more useful and convenient for accounting purposes (Pakseresht, 2010). 
Campbell (2002) and Tiwari (2010) mentioned that the brand must be carefully managed because a strong brand is always linked to marketing success and can be used to determine the premium value that a buyer would pay during a merger or acquisition process. Moreover, for corporate decision makers, a strong brand is useful to obtain better financial terms and add value to the firm in various situations such as a competitive market and/or an adverse business climate (Dutordoir, Verbeeten, \& Beijer, 2015). Thus, it significantly illustrates that brands are one of a firm's most important intangible assets. Iqbal, Qureshi, Shahid, and Khalid (2013) considered CSR as a key to sustain brands and achieve brand equity status. Several past studies found that CSR and CSR practices have a positive effect on brand equity (Fatma et al., 2015; Nair \& Bhattacharyya, 2019). These works measured brand equity based on Keller's and Aaker's approaches, however, this study would like to discover how CSR practices influence the financial approach of brand equity rather than customerbased brand equity.

\subsection{Development of Hypotheses}

Based on prior CSR and brand equity literature, 16 items were chosen to represent particular aspects of CSR practices - environmental, community, workplace and marketplace, and test their effect on financial-based brand equity. In each case, an expectation was developed based on previous literature. Figure 01 below shows the hypothesesbased model used in this study.



Figure 1: Hypotheses-based model

\subsubsection{Environmental CSR and Financial-based Brand Equity}

Environmental CSR is a result of an organization's initiative to act benevolently, of its own free will, for the sake of their stakeholders, as proposed in the Stakeholder Theory. An organization's act of preserving nature by saving energy and preventing wastage will also benefit the organization by reducing the organization's expenditure (Jones, Comfort, \& Hillier, 2005) as well as forming a good opinion of the organization in the minds of its customers
(Kippenberger, 1996) and enhance the brand equity (Cowan \& Guzman, 2018; Frengiah \& Yaacoub, 2019). Many scholars have studied the impact of environment-based CSR on financial-based brand equity. In a study conducted by Torres et al. (2012), it was observed that within 57 global brands originating from ten countries, major determinants of financial-based brand equity were strongly related to environmental CSR. This is supported by Ford and Stohl (2019) who posited that financial-based brand equity is significantly influenced by environmental CSR. Another study by Frengiah and Yaacoub (2019) stated that the determinants of financial-based brand equity include environmental CSR. Similar results are found in the work of Ting and Yin (2017), Stranieri, Orsi, Banterie, and Ricci (2018) and Lv et al. (2019). However, a contradictory result can be found in the works of (Feng et al., 2016; Yang \& Basile, 2019) who found a negative relationship between environmental CSR and financial-based brand equity among the Top 100 Best Global Brands Ranking and 78 firms respectively. Therefore, this study hypothesizes the relationship between environmental CSR and financialbased brand equity as follows:

$\mathbf{H}_{1}$ : Environmental CSR is positively correlated with financial-based brand equity

\subsubsection{Community CSR and Financial-based Brand Equity}

In the context of Stakeholder Theory, organizations realize their stakeholders' interest (particularly the society) by caring for their welfare. In response to this, they practised many altruistic activities such as making donations to needy people (Sen \& Bhattacharya, 2001). This influenced the customers' behaviour as they perceive that the money they spent on buying the organization's products was being put to a good cause. According to Porter and Kramer (2011), the customers' positive perceptions of a brand will improve the brand's reputation and directly increase the organizations' financial-based brand equity. As explained by Feng et al. (2016), community-based CSR is perceived as the main contributor to financial-based brand equity. Lee, Kim, and Ham (2018) and Lau (2019) also support this relationship. Additionally, other researchers have also confirmed the positive and significant influence of community-based CSR on financial-based brand equity (Farooq, Aguenaou, \& Amor, 2015; Lawal, May, \& Stahl, 2017; Hoque, Rahman, Molla, Noman, \& Bhuiyan, 2017; Bajic \& Yurtoglu, 2018; Lau, 2019). For instance, Farooq et al. (2015) found the positive effect of community CSR on financial-based brand equity in various industries such as business services, consumer goods, electronics, financial services and diversified industries from 2002 to 2010 in the United States. However, a study conducted by Simionescu 
and Dumitrescu (2018) demonstrated a negative relationship between community-based CSR and financialbased brand equity. Therefore, this study hypothesizes the relationship between community-based CSR and financialbased brand equity as follows:

$\mathbf{H}_{2}$ : Community CSR is positively correlated with financialbased brand equity.

\subsubsection{Workplace CSR and Financial-based Brand Equity}

The Theory of Stakeholders clearly proposes that organizations are duty bound to fulfil their workplace CSR activities to satisfy the stakeholders' interests. In order to satisfy the employees' interests as internal stakeholders, organizations are responsible for ensuring their employees' welfare because the employees are involved in the day-today operations of the business (Williams \& Adams, 2013). Jones et al. (2005) highlighted that every employer should strive to furnish effective working vibes and conditions for the employees with the aim of ensuring that the security and productivity of the human resources is at the highest level. Through these efforts it will boost the organization's image and, subsequently, the financial-based brand equity of the organization (Ghosh, 2018; Fornes et al., 2019). Empirical studies conducted by Yang and Basile (2019) and Lv et al. (2019) have stated that the workplace CSR is the main determinant of financial-based brand equity. Additionally, researchers have confirmed the positive and significant influence of workplace CSR on financial-based brand equity (Feng et al., 2016; Hoque et al., 2017; Ting \& Yin, 2018; Rahman, Rodríguez-Serrano, \& Lambkin, 2019). Meanwhile, some past studies have argued that the workplace CSR is the main factor in determining financialbased brand equity among insurance company in Ghana and 414 firms in India (Mensah et al., 2017; Nair \& Bhattacharyya, 2019). Therefore, this study hypothesizes the relationship between workplace CSR and financialbased brand equity as follows:

$\mathbf{H}_{3}$ : Workplace CSR is positively correlated with financialbased brand equity.

\subsubsection{Marketplace CSR and Financial-based Brand Equity}

From the Stakeholder Theory viewpoint, many organizations make every effort to publicize the ethicality of their business operations in order for their stakeholders, particularly their customers, to be aware of them. Conversely, if an organization acts unethically, it would reflect unfavorably on the brand equity of the organization and customers might boycott their brand due to their negative response to the organization's reputation. When an organization's actions are deemed ethical, customers react favorably to the brand image of the company (Hoque et al., 2017; Curras-Perez No Reference 2018; Lau, 2019). Many scholars have found that financial-based brand equity is significantly influenced by marketplace CSR (Eldomiaty, Soliman, Fikri, \& Anis, 2016; Kang \& Namkung, 2017; Ford \& Stohl, 2018; Lv et al., 2019). Similarly, Curras-Perez et al. (2018) and Lau (2019) stated that the determinants of financial-based brand equity include marketplace CSR, as well as environmental, community and workplace CSR. However, a few recent studies have revealed a negative relationship between marketplace CSR and financial-based brand equity (Mensah et al., 2017; Yang \& Basile, 2019). Therefore, this study hypothesizes the relationship between marketplace CSR and financial-based brand equity as follows:

$\mathbf{H}_{4}$ : Marketplace CSR is positively correlated with financial-based brand equity.

\section{Research Methodology}

This study used content analysis to analyze company annual reports to determine the extent of CSR practices reported by Malaysia's Top 100 Brands that are PLCs. Content analysis was considered as an appropriate method to analyse the extent of disclosures. This method consistent with prior studies (for example, Choi, 1999; Mohd Ghazali, 2007; Esa \& Mohd Ghazali, 2012; Esa \& Zahari, 2016a; Esa \& Zahari, 2016b). The company annual reports of Malaysia's Top 100 Brands in 2016 were downloaded from the Bursa Malaysia website and examined for references to CSR practices. The current study was unable to present a full set of 100 PLCs due to the 2016 annual reports of eight companies not being able to be accessed from Bursa Malaysia or their company websites. Thus, only 92 companies were included in the final selection. In many cases, the annual report of each company consisted of the company's financial and non-financial information reports and therefore, any information regarding the companies' CSR practices could be found in these reports (Rowbottom \& Lymer, 2010). To measure the CSR practices, the current study adopted and integrated 16 checklist items from Anas, Abdul Rashid, and Annuar (2015) and Abd Rahim (2016). Specifically, four items were used to measure environmental CSR, five items were used for community CSR and four items for workplace CSR. A score of " 1 " was given if any item on the checklist was mentioned by a company in their annual report, whereas a score of " 0 " denoted the absence of a CSR.

Brand equity is the dependent variable in the current study. Brand equity value was determined to calculate the 
value of the brands in its league tables using the Royalty Relief Approach (The Brand Finance Group, 2016). This approach involved estimating the likely future sales that could be attributed to a brand and then a calculation of a royalty rate would be charged for the use of the brand i.e. what the owner would have to pay for the use of the brandassuming it were not already owned. Brand value can be defined as 'the value of the trademarks (and related marketing intellectual property and goodwill attached to it) within the branded business' (The Brand Finance Group, 2016). Additionally, Brand Finance provided the formula below to calculate the brand value, which was adopted for this study.

\section{Brand Strength Index (BSI) x Brand 'Royalty Rate' x Brand Revenues $=$ Brand Value}

According to The Brand Finance Group (2016), there are six procedures required to measure the brand value. These include: (i) the brand strength on a scale of 0 to 100 , based on the number of attributes such as emotional connection, financial performance and sustainability, are calculated. This score is known as the Brand Strength Index; (ii) the royalty rate ranges for the respective brand sectors were determined. This was done by reviewing comparable licensing agreements sourced from Brand Finance's extensive database of licensing agreements and other online databases; (iii) the royalty rate was calculated where the brand strength score was applied to the royalty rate range to arrive at a royalty rate; (iv) brand specific revenues estimating a proportion of parent company revenues attributable to a specific brand were determined; (v) the forecast brand specific revenues were determined using historic revenues, equity analyst forecasts and economic growth rates and (vi) the royalty rate was applied to the forecast revenues to derive brand revenues, then the brand revenues were discounted post tax to a net present value which equals the brand value. Data was analyzed using normality test, descriptive and correlation test by means of IBM Statistical Package for Social Science (SPSS) Statistics for Windows, Version 24.0.

\section{Findings and Discussion}

This study examined the CSR practices of 92 companies from Malaysia's Top 100 Brands in 2016. The first data analysis related to the normality test. Table 1 shows the result of the normality test where the values of Kolmogorov-Smirnov and Shapiro-Wilk were examined. Findings in Table 1 show that all variables used in this study (environmental, community, workplace, marketplace and brand equity) recorded p-values less than .05 (p-value $<.05$ ) for both Kolmogorov-Smirnov and Shapiro-Wilk tests. This indicates that the data is not normally distributed and, therefore, the parametric tests need to be checked further.

The next analysis was the descriptive test. Table 1 presents the results of minimum, maximum, medium and standard deviation of all constructs. In this study, the means value shows the average percentage for each company in disclosing CSR practices. For instance, the mean value for environmental CSR was $.6766 \%$ and this indicates that the average percentage for each company to disclose CSR for environmental is $67.66 \%$. It means that in 2016, each company disclosed $67.66 \%$ of environmental CSR in their annual reports. Meanwhile, the average percentage for each company to disclose community CSR, workplace CSR and marketplace CSR is $68.26 \%, 76.90 \%$ and $63.77 \%$ respectively. In addition, the average value for $\mathrm{BE}$ for each of company was RM $1,866.77$. By ranking, workplace CSR is in the first place, followed by community CSR, environmental CSR and marketplace CSR.

With regard to standard deviation values, environmental CSR is recorded at .30004, while community CSR was at .24834. Meanwhile, the values of standard deviation for workplace CSR, marketplace CSR and brand equity were at $.25205, .36532$ and 5097.22 respectively. The smallest standard deviation is for community CSR, implying that the percentage of disclosures for community CSR by companies is less dispersed and is highly concentrated around the mean. Therefore, most of the companies indicate as many as 3 out of 5 checklist items. Conversely, the largest standard deviation is brand equity, denoting that the brand equity of the companies is more dispersed and is less concentrated around the mean. Hence, most of the companies' brand equity differs from each other and there is a huge disparity between them.

Moreover, Table 1 also shows the value of the minimum and maximum level of each variable. Findings show that the minimum level for all CSR practices is 0. The possible reason for the latter is the selected company may be focusing on contributing to one or two CSR's activities. Meanwhile, the maximum level of all CSR practices is 1 which means it is possible for the company to make a contribution to all four CSR practices and disclosed in their annual reports. In addition, Table 1 also shows that the minimum value of brand equity is RM31.43 million, while the highest value is at RM45,007.76 million. Furthermore, on average, the marketplace CSR is the lowest of the constructs indicated by the results $(\mathrm{M}=.677, \mathrm{SD}=.300)$. Meanwhile, the workplace CSR represents the highest average $(\mathrm{M}=.769, \mathrm{SD}=.252)$. 
Table 1: Results of normality tests and descriptive statistics $(\mathrm{N}=92)$

\begin{tabular}{|c|c|c|c|c|c|c|c|c|}
\hline \multirow{2}{*}{ Construct } & \multicolumn{2}{|c|}{ K-S } & \multicolumn{2}{|c|}{ S-W } & \multirow{2}{*}{ Min } & \multirow{2}{*}{ Max } & \multirow{2}{*}{ Mean } & \multirow{2}{*}{ SD } \\
\cline { 2 - 9 }$n$ & Stats & Sig. & Stats & Sig. & .000 & 1.00 & .677 & .300 \\
\hline Environmental CSR & .303 & .000 & .807 & .000 & .00 & .683 & .248 \\
\hline Community CSR & .174 & .000 & .902 & .000 & .000 & 1.00 & .252 \\
\hline Workplace CSR & .263 & .000 & .802 & .000 & .000 & 1.00 & .769 & .638 \\
\hline Marketplace CSR & .252 & .000 & .820 & .000 & .000 & 1.00 & .365 \\
\hline $\begin{array}{c}\text { Financial-based brand } \\
\text { equity }\end{array}$ & .359 & .000 & .332 & .000 & 31.43 & 45007.76 & 1866.76 & 5097.22 \\
\hline
\end{tabular}

Notes: K-S = Kolmogorov-Smirnov; S-W = Shapiro-Wilk; SD = Std. Deviation

Additionally, Table 2 displays the correlation coefficient between the CSR practices and financial-based brand equity. Since the data is not normally distributed, the parametric test (Spearman's rho) is used to determine the relationship between each of the CSR's activities and companies' brand equity. It also determines the strength of both variables. The results show that the estimated Spearman Correlation between environmental CSR and financial-based brand equity is .020 while the critical significance value (p-value) is .05 , thus Hypothesis 1 was supported by results (correlation $=.243$; Sig. (2-tailed) $=.000$ ). The results are in line with past studies which stated that the determinants of financial-based brand equity include the role of environmental CSR (Ting \& Yin, 2017; Stranieri et al., 2018; Lv et al., 2019). By contrast, past works of Feng et al. (2016) and Yang and Basile (2019) found a negative relationship between environmental CSR and financial-based brand equity.

Moreover, the community CSR (as shown in Table 2) also positively correlated with financial-based brand equity by results $($ correlation $=.407$; Sig. $(2$-tailed $)=.000)$, hence Hypothesis 2 was supported and indicates that $40.7 \%$ of variation in the financial-based brand equity is explained by the community CSR. These findings are supported by previous studies by Hoque et al. (2017), Lee et al. (2018), and Lau, (2019) who also proved that the community-based CSR is perceived as the main contributor to financial-based brand equity. Another study by Simionescu and Dumitrescu (2018) revealed a negative relationship between community CSR and financial-based brand equity.

Furthermore, Hypothesis 3 was also supported by $($ correlation coefficient $=.409$; Sig. $(2$-tailed $)=.000)$. This indicates that workplace CSR is positively correlated to financial-based brand equity. The results are similar to the past works of Hoque et al. (2017), Ting and Yin (2018), and Lv et al. (2019) who found significant positive relationship between workplace CSR and financial-based brand equity. Indeed, some studies argued that the workplace CSR plays the major role in determining financial-based brand equity (Mensah et al., 2017; Nair \& Bhattacharyya, 2019). Similarly, marketplace CSR (Hypothesis 4) was shown to have a correlation with brand equity by results (correlation coefficient $=.559$; Sig. (2-tailed) $=.000)$. The consistent findings can also be found in the studies of financial-based brand equity by Kang and Namkung (2017), Ford and Stohl (2018) and Lv et al., (2019). However, a few studies have demonstrated a negative relationship between marketplace CSR and financial-based brand equity (Mensah et al., 2017; Yang \& Basile, 2019).

In brief, all four types of CSR practices conducted by ninety two PLCs in Malaysia's Top 100 Brands in 2016 are positively correlated to financial based brand equity. Thus, all hypotheses were supported. With regard to Stakeholder Theory, the findings set out in Table 2 show that the theory is well supported and consistent with previous studies (Anas et al., 2015; Yang \& Basile, 2019; Lv et al., 2019).

Table 2: Spearman's Rho Correlation $(\mathrm{N}=92)$

\begin{tabular}{|l|l|l|l|}
\hline Construct/Hypothesis & $\begin{array}{l}\text { Correlation } \\
\text { coefficient }\end{array}$ & $\begin{array}{l}\text { Brand } \\
\text { equity }\end{array}$ & Decision \\
\hline Environmental CSR (H1) & Sig. (2-tailed) & $\begin{array}{l}.243^{*} \\
.020\end{array}$ & Supported \\
\hline Community CSR (H2) & Sig. (2-tailed) & $\begin{array}{l}.407^{* *} \\
.000\end{array}$ & Supported \\
\hline Workplace CSR (H3) & Sig. (2-tailed) & $\begin{array}{l}.409^{* *} \\
.000\end{array}$ & Supported \\
\hline Marketplace CSR (H4) & Sig. (2-tailed) & $\begin{array}{l}.559^{* *} \\
.000\end{array}$ & Supported \\
\hline
\end{tabular}

Notes: *Correlation is significant at the .05 (2-tailed); **Correlation is significant at the .01 (2-tailed)

\section{Conclusions}

The main objective of this study was to examine the relationship between the four CSR practices and financialbased brand equity among Malaysia's Top 100 Brands in 2016. The findings suggest that all CSR practices, namely environmental, community, workplace and marketplace, have a significant and positive correlation with financialbased brand equity. It clearly indicates that if the company reports on more of its CSR practices, the brand equity value will be increased as well. Importantly, CSR practices will help strengthen the BE which could become one of the vital elements of a company's competitive advantage and success in the highly competitive world of top brand companies.

Furthermore, it proved that the Stakeholder Theory is useful for creating a high value of brand equity. However, this study has some limitations. Firstly, the current study 
only measured the CSR practices of 92 PLCs in 2016, therefore, future studies should extend the duration for studying the effects of CSR activities on brand equity. In addition, this study only involved content analysis, therefore, gathering information from business leaders or key executives is critical in future studies. On top of that, a future study could concentrate more on the quality of CSR practices than CSR disclosure. Finally, a future study could deploy a mix method of measuring brand equity and combine the results from financial-based brand equity and consumer-based brand equity.

\section{References}

Aaker, D. (1991). Managing Brand Equity. New York, NY: The Free Press.

Abd Rahim, N. (2016). Assessing the influence of ethical leadership behaviors, leadership styles and leadership roles as determinants of online corporate social responsibility (CSR) disclosures in Malaysia (Doctoral dissertation). University of Gloucestershire, Gloucestershire, England.

Anas, A., Abdul Rashid, H., \& Annuar, H. (2015). The effect of award on CSR disclosures in annual reports of Malaysian PLCs. Social Responsibility Journal, 11(4), 831-852.

Bajic, S., \& Yurtoglu, B. (2018). Which aspects of CSR predict firm market value? Journal of Capital Markets Studies, 2(1), 50-69.

Barney, J. B., \& Hansen, M. H. (1994). Trustworthiness as a source of competitive advantage. Strategic Management Journal, 15(S1), 175-190. doi:10.1002/smj.4250150912

Bhattacharya, S. (2017). Does corporate social responsibility contribute to strengthen brand equity? An empirical study. International Review on Public and Nonprofit Marketing, 14(4), 513-533. doi: $10.1007 / \mathrm{s} 12208-017-0185-\mathrm{z}$

Bhattacharya, S., \& Kaursar, A. (2016). Study on corporate social responsibility as strategic instrument for creating sustainable corporate brand value: An analysis with structural equation modelling. Management and Labour Studies, 41(2), 88-106.

Campbell, M. C. (2002). Building brand equity. International Journal of Medical Marketing, 2(3), 208218.

Carroll, A. B. (1991). The pyramid of corporate social responsibility: Toward the moral management of organizational stakeholders. Business Horizons, 34(4), $39-48$.

Choi, J-S. (1999). An investigation of the initial voluntary environmental disclosures made in Korean semi-annual reports. Pacific Accounting Review, 11(1), 73-102.

Clarkson, M. (1995). A stakeholder framework for analyzing and evaluating corporate social performance. Academy of Management Review, 20(1), 92-117.

Clarke, T., \& Clegg, S. (1998). Changing paradigms: The transactions of management knowledge for the $21^{\text {st }}$ century. London, England: Harper Collins.

Cone Inc. (2017). The 2017 Cone communications CSR study. Boston, MA: Cone Inc. Retrieved July 6, 2019, from http://www.conecomm.com/insightsblog/2017/5/25/announcing-the-2017-conecommunications-csr-study

Cowan, K., \& Guzman, F. (2018). How CSR reputation,sustainability signals, and country-of-origin sustainability reputation contribute to corporate brand performance: An exploratory study. Journal of Business Research. [In Press] https://doi.org/10.1016/j.jbusres.2018.11.017

Curraz-Perez, R., Dolz-Dolz, C., Miquel-Romero, M.J., \& Sanchez-Garcia, I. (2018). How social, environmental, and economic CSR affects consumer- perceived value: Does perceived consumer effectiveness make a difference? Corporate Social Responsibility and Environmental Management, 25,733-747. doi: 10.1002/csr. 1490

Clarkson, M. B. (1995). A stakeholder framework for analyzing and evaluating corporate social performance. Academy of Management Review, 20(1), 92-117.

Deanna Wang, H-M., (2010). Corporate social performance and financial- based brand equity. Journal of Product \& Brand Management, 19(5), 335-345.

Ding, D. K., Ferreira, C., \& Wongchoti, U. (2016). Does it pay to be different? Relative CSR and its impact on firm value. International Review of Financial Analysis, 47, 86-98.

Dutordoir, M., Verbeeten, F. H., \& Beijer, D. D. (2015). Stock price reactions to brand value announcements: Magnitude and moderators. International Journal of Research in Marketing, 32, 34-47.

Eldomiaty, E., Soliman, A., Fikri, A., \& Anis, M. (2016). The financial aspects of the corporate responsibility index in Egypt: A quantitative approach to institutional economics. International Journal of Social Economics, 43(3), 284-307.

Esa, E., \& Mohd Ghazali, N.A. (2012). Corporate social responsibility and corporate governance in Malaysian Government Linked Companies. Journal of Corporate Governance, 12(3), 292-305.

Esa, E., \& Zahari, A.R. (2016a). Corporate social responsibility: ownership structures, board characteristics and the mediating role of board compensation. Procedia Economic and Finance, 35, 3543. 
Esa, E., \& Zahari, A. R. (2016b). Do board educational background, occupational background and ownership structure matter for directors' remuneration disclosure? Some Malaysian evidence. In Ethical and Social Perspectives on Global Business Interaction in Emerging Markets (pp. 150-164), IGI Global.

Evans, G. W., \& Kantrowitz, E. (2002). Socioeconomic status and health. The potential role of environmental risk exposure. Annual Review Public Health, 23, 303331.

Faisal, N. M. (2010). Sustainable supply chains: A study of interaction among the enablers. Business Process Management Journal, 16, 508-529.

Fatma, M., Rahman, Z., \& Khan, I. (2015). Building company reputation and brand equity through CSR: The mediating role of trust. International Journal of Bank Marketing, 33(6), 840-856.

Farooq, O., Aguenaou, S., \& Amor, M.A. (2015). Corporate social responsibility policy and brand value. The Journal of Applied Business Research, 31(6). doi: 10.19030/jabr.v31i6.9463

Feng, M., Wang, X., \& Kreuze, J. G. (2017). Corporate social responsibility and firm financial performance: comparison analyses across industries and CSR categories. American Journal of Business, 32(3/4), 106133.

Feng, Y., Yoon, Y., \& He, Y. (2016). The impact of corporate social responsibility on brand value: An empirical study of Top 100 Global Brands. International Journal of Business and Social Sciences, 7(10), 61-71.

Ford, B. R., \& Stohl, C. (2019). Does CSR matter? A longitudinal analysis of product reviews for CSRassociated brands. Journal of Brand Management, 26(1), 60-70.

Fornes, G., Lopez, B., de Haan, M. B., \& Blanch, J. (2019). Best practice example of CSR and S\&E engagement in emerging economies: Analysis of a case study based in China. Journal of Asia Business Studies, 13(1), 133-154.

Fox, S., \& Stallworth, L. E. (2009). Building a framework for two internal organizational approaches to resolving and preventing workplace bullying: Alternative dispute resolution and training. Consulting Psychology Journal Practices Responsibility, 61, 220-241.

Ghosh, K. (2018). How and when do employees identify with their organization? Perceived CSR, first party (in) justice, and organizational (mis)trust at workplace. Personnel Review, 47(5), 1152-1171.

Golob, U., \& Podnar, K. (2019). Researching CSR and brands in the here and now: An integrative perspective. Journal of Brand Management, 26(1), 1-8. doi: 10.1057/s41262-018-0112-6
Heinberg, M., Ozkaya, H. E., \& Taube, M. (2018). Do corporate image and reputation drive brand equity in India and China? - Similarities and differences. Journal of Business Research, 86, 259-268.

Hoque, N., Rahman, A. R. A., Molla, R. I., Noman, A. H. M., \& Bhuiyan, M. Z. H. (2017). Is corporate social responsibility pursuing pristine business goals for sustainable development? Corporate Social Responsibility and Environmental Management, 25, 1130-1142. doi: $10.1002 / \mathrm{csr} .1527$

Iqbal, F., Qureshi, A. R., Shahid, N., \& Khalid, B. (2013). Impact of corporate social responsibility (CSR) on brand equity (B.E). Unpublished Degree Final Year Project Paper, University of Central Punjab, Lahore, Punjab, Pakistan.

Jones, P., Comfort, D., \& Hillier, D. (2005). Corporate social responsibility and the UK's top ten retailers. International Journal of Retail \& Distribution Management, 33(12), 882-892.

Jones, R. (2005). Developing a stakeholder model for brand equity. Journal of Brand Management, 13(1), 1032.

Kang, J. W., \& Namkung, Y. (2017). The effect of corporate social responsibility on brand equity and the moderating role of ethical consumerism: the case of Starbucks. Journal of Hospitality \& Tourism Research, 42(7), 11301151.

Kantabutra, S., \& Avery, G., (2013). Sustainable leadership: Honeybee practices at a leading Asian industrial conglomerate. Asia-Pacific Journal of Business Administration, 5, 36-56.

Keller, K. L. (2003). Strategic Brand Management: Building, Measuring, and Managing Brand Equity (2nd ed.). Upper Saddle River, NJ: Prentice Hall.

Kim, H. L., Rhoub, Y., Uysalc, M., \& Kwond, N. (2017). An examination of the links between corporate social responsibility (CSR) and its internal consequences. International Journal of Hospitality Management, 61, 26-34.

Kippenberger, T. (1996). The environment as stakeholder: Does it make sense to develop a corporate environmental policy? The Antidote, 1(2), 21-22.

Lau, C. K. (2019). The economic consequences of business sustainability initiatives. Asia Pacific Journal of Management, Springer, 36(4), 937-970. doi: 10.1007/s10490-018-9623-7

Lee, S., Kim, B., \& Ham, S. (2018). Strategic CSR for airlines: Does materiality matter? International Journal of Contemporary Hospitality Management, 30(12), 3592-3608.

Lv, W., Wei, Y., Li, X., \& Lin, L. (2019). What dime nsion of CSR matters to organizational resilience? Evidence from China. Sustainability 11(2019), 1561. 
doi: $10.3390 /$ su11061561

Menon, A., \& Menon, A. (1997). Enviropreneurial marketing strategy: The emergence of corporate environmentalism as market strategy. Journal of Marketing, 61(1), 51-67.

Mensah, D. R., Yensu, J., \& Atuilik, D.A. (2017). Building brand equity through the influence of corporate social responsibility (CSR): A case study of Hollard InsuranceKumasi. Journal of Management Research, 9(1), 146163.

Mohd Ghazali, N.A. (2007). Ownership Structure and corporate social responsibility disclosure: some Malaysian evidence. Corporate Governance, 7(3), 251266.

Nair, A. K. S., \& Bhattacharyya, S. S. (2019). Mandatory corporate social responsibility in India and its effect on corporate financial performance: Perspectives from institutional theory and resource- based view. Business Strategy and Development, 2, 106-116.

Pakseresht, A. (2010). Brand equity and corporate responsibility-A review of brand valuation methods (Unpublished Master Thesis). Swedish University of Agricultural Sciences, Uppsala, Sweden.

Piercy, N. F., \& Lane, N. (2009). Corporate social responsibility: Impacts on strategic marketing and consumer value. The Marketing Review, 9(4), 335-360.

Porter, M. E., \& Kramer, M. R. (2011). Creating shared value. Harvard Business Review, 89(1/2), 62-77.

Prakash, G., Choudharyb, S., Kumarc, A., Garza-Reyesd, J. A., Khane, S. A. R, \& Panda, T. K. (2019). Do altruistic and egoistic values influence consumers' attitudes and purchase intentions towards eco-friendly packaged products? An empirical investigation. Journal of Retailing and Consumer Services, 50, 163-169.

Rahman, M., Rodríguez-Serrano, M. Á., \& Lambkin, M. (2019). Brand equity and firm performance: The complementary role of corporate social responsibility. Journal of Brand Management, 26(6), 691-704. doi:10.1057/s41262-019-00155-9

Rowbottom, N., \& Lymer, A. (2010). Exploring the use and users of narrative reporting in the online annual report. Journal of Applied Accounting Research, 11(2), 90-108.

Sen, S., \& Bhattacharya, C. B. (2001). Does doing good always lead to doing better? Consumer reactions to corporate social responsibility. Journal of Marketing Research, 38(2), 225-243.

Shahin, A., \& Zairi, M. (2007). Corporate governance as a critical element for driving excellence in corporate social responsibility. Journal of International Quality and Reliability Management, 24, 753-770.

The Brand Finance Group. (2016). The Brand Finance Top 100 Malaysia Brands 2016. Retrieved February 24, 2019 , from http://brandfinance.com/images/upload/brand_finance_ malaysia 100.pdf

Tiba, S., van Rijnsoever, F. J., \& Hekkert, M. P. (2018). Firms with benefits: A systematic review of responsible entrepreneurship and corporate social responsibility literature. Corporate Social Responsibility and Environmental Management, 26, 265-284.

Ting, P-H., \& Yin, H-Y. (2018). How do corporate social responsibility activities affect performance? The role of excess control right. Corporate Social Responsibility and Environmental Management, 25, 1320-1331.

Tiwari, M. K. (2010). Separation of brand equity and brand value. Global Business Review, 11(3), 421-434.

Torres, A., Bijmolt, T. H., Tribó, J. A., \& Verhoef, P. (2012). Generating global brand equity through corporate social responsibility to key stakeholders. International Journal of Research in Marketing, 29(1), 13-24.

Singh Dara Singh, K., \& Islam A. M. (2017). Validating an instrument for measuring brand equity of CSR driven organizations in Malaysia. Management \& Marketing. Challenges for the Knowledge Society, 12(2), 237-251.

Stranieri, S., Orsi, L., Banterie, A., \& Ricci, E. C. (2018). Sustainable development and supply chain coordination: The impact of corporate social responsibility rules in the European Union food industry. Corporate Social Responsibility and Environmental Management, 26, 481-491.

Waddock, S. (2004). Parallel universes: Companies, academics, and the progress of corporate citizenship. Business and Society Review, 109(1), 5-42.

Williams, S. J., \& Adams, C. A. (2013). Moral accounting? Employee disclosures from a stakeholder accountability perspective. Accounting, Auditing \&Accountability Journal, 26(3), 449-495.

Willmott, H. (2010). Creating 'value' beyond the point of production: Branding, financialization and market capitalization. Organization, 17(5), 517-542.

Yang, J., \& Basile, K. (2019). The impact of corporate social responsibility on brand equity. Marketing Intel ligence \& Planning, 37(1), 2-17. 